\title{
Including Human Values in Management Education: Experiential Insights
}

\author{
C. Panduranga Bhatta \\ Professor, Management Centre for Human Values, \\ Indian Institute of Management Calcutta, India \\ Email: cpbhatta@iimcal.ac.in
}

\author{
Doi:10.5901/jesr.2013.v3n7p197
}

\section{Abstract}

This paper makes a critical analysis of the need and method for instilling human values in management students, derived from an understanding of the role of the Management Centre for Human Values (MCHV), a centre concretised in and by the Indian Institute of Management Calcutta (IIMC) way back in April 1992. The case of MCHV is used here to understand and appreciate the responsibilities of educational institutions towards a global world. MCHV has come a long way in "integrating" courses on human values into the mainstream post-graduate programs administered by IIMC. Human value courses offered by the Centre make an attempt to cultivate a global outlook, love for nature and a concern for fellow human beings and the environment in management students. These courses touch the distinct dimensions of human personality such as developing; aesthetic sensibilities, socially desirable moral values and finally, the inner dimension of spiritual growth. The human values agenda of MCHV is to make students more socially concerned, compassionate, liberal, inclusive, ethical, and humane. The courses offered by the Centre, also helps developing inclusive leaders who would include humans, religions and environment in their programmes. For achieving this purpose, MCHV courses use universally applicable syllabus which is multidisciplinary in nature. This paper makes a journey through the experiences of the Centre to share some of its success stories and also to share some of its concerns.

\section{Introduction}

Human values are eternal and universal and they do not change according to time or region. Harvard Business School has started an Oath taking ceremony for its MBA students which is popularly known as "The MBA Oath." In this Oath, as the students become business leaders, they are asked to recognize their role in society. They are required to promise that they will manage their enterprises with loyalty and care, and will not advance their personal interests at the expense of their enterprise or society. They are also to assure that they will refrain from corruption, unfair competition, or business practices harmful to society besides protecting the rights and dignity of all people affected by their enterprises, and will oppose discrimination and exploitation. This Oath emphasizes the importance of a myriad of core values like honesty, equality, selflessness, sincerity, ethical actions, etc., which have been insisted from time immemorial in all countries and cultures.

The convocation address found in one of the philosophical texts viz. Taittiriya Upanishad is important to understand the significance of human values. In this convocation address the students are urged to honour superiors and to give in proper manner and spirit, in joy and humility, in fear and compassion. This address tries to inculcate in students, qualities such as social consciousness based on love for humanity, character, honesty based on moral law and, discipline based on the sense of duties and responsibilities of an individual. This age old convocation address and "The MBA Oath" similarly urge the students to follow the righteous path always without any exception.

Let us look at the vision and mission statements of the top Business Schools such as Harvard, Sloan, Stanford, Indian Institutes of Management (IIMs) set up by the Government of India in Calcutta, Ahmadabad, and Bangalore. Had they believed that human values and ethics are not important in the corporate world, they would not have any reference to values and ethics in their vision and mission statements. ${ }^{3}$ The path breaking empirical research conducted by Srikant Datar, David A Garvin and Patrick G Cullen of Harvard Business School is published in a book viz. "Rethinking the MBA: Business Education at a Cross Roads". To improve the ethical and value dimension of B-School students they have suggested "Knowing, Doing and Being model" of education in their book. ${ }^{4}$ Being part includes:

Values, attitudes, beliefs that constitute one's character \& worldview, being aware of the line between right \& wrong, the preferred treatment of others, the purpose \& goals of organisations \& the behaviours that exemplify integrity, honesty, \& fairness. The buzz word in today's corporate circle is 3Ps, Planet, People and Profit. If values and ethics are not 
congruent with profit making, CSR and Environmental auditing would not have been insisted in the corporate world.

The vision of Indian Institute of Management Calcutta is to produce ethically oriented and caring leaders who manage change and transformation'. This institute houses the Management Centre for Human Values (MCHV) which was created in April, 1992 to initiate teaching, research, training and offer consultancy on Human Values and Ethics in Management. ${ }^{5}$ It is significant in this context to note that the premiere technological institutes in India and abroad house a Humanities Department.

This indicates a felt need for courses on humanities in such institutes, where technical knowledge takes the cake. It may be noted here that, in one form or other, in the global picture of world class institutes, the need to propagate a holistic education over that of mere specialisation is taking center stage. ${ }^{6}$

An attempt is made here through the experiences of MCHV to explain the significance of teaching human values and the methodology adopted for the same. While delivering courses ranging across sessions for post-graduates to executives, MCHV has come a long way in "integrating" courses on human values into the mainstream post-graduate programs administered by $\mathrm{IIMC}^{7}$. MCHV courses attempt to integrate history and mythology, Eastern and Western ethos, sciences and humanities, academic and industrial, fiction and real-life,- to develop a personality that helps human life, society and civilization thrive in the contemporary world of heterogeneity. A self-reflexive vision of the world based on humanistic-thought traditions provided through these courses would make a powerful impact on the participating students to look beyond narrow, short-term individualistic motives that generally drive human beings. The larger vision, derived from multiple thought systems encompasses the good of humankind and the welfare of society. This vision in turn, will help cultivate flexibility by admitting diversity besides championing the cause of human values. As stressed in these courses, human values for a diverse world would include inclusivism, interdependence, interconnectedness, ethics and compassion in every field of human activity. The courses deal with a wide range of issues related to personality development and provide ideas, opinions, experiences, beliefs, perspectives and futuristic thoughts which are of immense value to all those who aim to thrive in different fields in today's complex and globalised world.

MCHV courses mainly rest on the three Pillars of Inclusion viz. (1) The Pillar of Environmental Inclusion, (2) The Pillar of Religious Inclusion and (3) The Pillar of Human Inclusion. It becomes necessary to spell out the reasons for developing such inclusive insights and the method adopted in developing these three pillars. What is attempted next is a background survey of these three pillars of inclusion which are the bedrocks for the courses offered by MCHV. A detailed discussion is also entertained here on the importance of concepts and materials used in developing these three pillars of inclusion. The concepts and materials are multi-disciplinary and universally applicable and hence easily replicable.

\section{The Pillar of Environmental Inclusion}

Ancient Indians' concern for environment as documented in the ancient Indian scriptures and literature may be compared with the concerns expressed by the contemporary ecologists. It must be pointed out that the contemporary ecologists start with the assumption that we have to take care of the environment as it affects our living. On the other hand, the ancient Indians' concern started with the assumption that they were a part of a larger existence. It is to be noted here that the Norwegian philosopher Arne Naess first coined the phrase 'deep ecology' to describe deep ecological awareness. Deep ecology is rooted in a perception of reality that extends beyond the scientific framework to an intuitive awareness of the oneness of all life, the interdependence of its multiple manifestations. Arne Naess says:

Care flows naturally if the 'self' is widened and deepened so that protection of free Nature is felt and conceived as protection of ourselves ... Just as we need no morals to make us breathe. [. . .]. [So] if your 'self' in the wide sense embraces another being, you need no moral exhortation to show care. [... ].

You care for yourself without feeling any moral pressure to do it ... If reality is like it is experienced by the ecological self, our behaviour naturally and beautifully follows norms of strict environmental ethics. ${ }^{8}$

We must note that the ancient Indian scriptures which are the oldest documented scriptures of mankind (as early as $1500 \mathrm{BC}$ ); the philosophical and theoretical texts; and Sanskrit classical literature clearly enunciated a nature-friendly world-view that prompted the ancient Indian civilization not merely to treat the environment with reverence, but also create an awareness amongst themselves that the great forces of nature - the earth, the water, the fire, the air, the ether - as well as various orders of life including plants, trees, forests and animals are all bound to each other within the great rhythms of nature. ${ }^{9}$ The mythological, the legal and the fictional narratives of nature in Ancient Indian texts also historicize the interconnectivity and hence the inclusion of nature in human practices; the echoes of which are so 
compelling in contemporary discourse cited above. Reverence for animals is also evident in the ancient mythologies. The bull, the eagle, the lion, the elephant, the swan, the cow, the mouse and many more are the vehicles of various Gods and Goddesses. The point conveyed here is that the animals are not to be looked upon as creatures to be cruelly exploited but to be seen as partners with human beings in the journey of life. Even if one does not have any overflowing love for the plants and insects, at least one's self-love should dictate that one's survival is tied up with the survival of the plants and insects. ${ }^{10}$ It must be pointed out here that the environmental inclusivity and sustainability have been discussed even in art, architecture and literature. Sanskrit poetry was a product of those who lived amidst hills, lakes, animals, trees and flowers and had all the time to feel the full impact of Nature in its beauty, severity and sublimity. The description of Sakuntala, the female protagonist in Kalidasa's famous Sanskrit drama viz. Abhijnanasakuntalam, leaving the surroundings of her foster father's hermitage is one of the most moving scenes in the world's entire dramatic literature. Brought up from infancy in the lap of nature, Sakuntala had a sisterly affection for the flora and fauna of the place. The strings which joined her heart to them seemed to burst as she said good-bye to them tearfully. Such examples are plenty in Sanskrit literature and provide good insights to students by adding one more perspective for developing an environmental friendly life style. ${ }^{11}$

\section{Pillar of Religious Inclusion}

The history of religion bears ample witness to the dual and rather contradictory role of religion throughout the ages. It has always inspired people to attain great heights in the realm of moral and spiritual life besides promoting solidarity, peace and harmony in society. This constitutes the bright side of religion. But at the same time there is also a dark side of religion, which brings unhappiness and suffering to people. This is mainly due to a persistent confusion between the deeper aspect of religion which constitutes its truth and its external aspect or structure which ordinarily serves as a means to attain that truth. The essence and purpose of religion has to be clearly distinguished from its external structure. Any exclusive stress on the external side of religion often leads to undesirable consequences. His Holiness The Dalai Lama says that religions may differ from each other significantly in; metaphysics, concept of God, ways to salvation or liberation, mythology, rules, customs, rites and rituals etc. But more or less they agree on the basic ethical principles like commitment to truth, compassion for the weak, and self control. While the other components of religion divide people on religion, ethics has the powerful potential to unite them on a common footing as illustrated in the golden rule appearing in almost all religions. He says that it is the intrinsic responsibility of World Religions to maintain World Peace.

And he furthers his claim on Religious inclusivity when he states that Universal Humanitarianism and Compassion "are in accordance with the ethical teachings of all world religions." He says:

I maintain that every major religion of the world - Buddhism, Christianity, Confucianism, Hinduism, Islam, Jainism, Judaism, Sikhism, Taoism, Zoroastrianism - has similar ideals of love, the same goal of benefiting humanity through spiritual practice, and the same effect of making their followers into better human beings... The common goal of all moral precepts laid down by the great teachers of humanity is unselfishness. ${ }^{12}$

India is the birth place of many religions. The ancient Indian religion viz. Hinduism went through many transformations, absorbing the tenets of Jainism, Buddhism, and Sikhism, to name a few. They may be interpreted as reform movements from within the fold of Hinduism put forth to meet the special demands of the various stages of its' development. Zoroastrianism, Islam, and Christianity have been so long in India that they have become native to the soil and are deeply influenced by the atmosphere of native religions.

The contemporary political debate in India has been between the secular principle, which is the identification of a citizen as equal in the eyes of law, notwithstanding his/her religious and racial and economic background, and the Indian concept of sarva-dharma-samabhava, i.e. equal respect for all religions, or dharma nirapeksha, i.e. neutrality between religions. In this context it becomes important to refer to His Holiness The Dalai Lama who emphasizes on the significance of religion; the acceptance and legitimization of religion. What is important here is His Holiness' stance:

Rather, I try to think of how I as a Buddhist humanitarian can contribute to human happiness. ${ }^{13}$

That religion matters, and religious identity matters is a fascinating thing to say in today's secular discourse. In His Holiness' poignant words:

While pointing out the fundamental similarities between world religions, I do not advocate one particular religion at the expense of all others, nor do I seek a new 'world religion'. All the different religions of the world are needed to enrich 
human experience and world civilization. Our human minds, being of different calibre and disposition, need different approaches to peace and happiness. ${ }^{14}$

Thus, the interest should be, not secularism at the expense of religion, but to respect a social and cultural identity of an individual first. As His Holiness has rightly commented, it is important to identify and eulogise efforts made in any part of the world to "better understanding among religions", rather than eradicate religious identity. If interconnected and inclusive humanitarianism is the common denominator of every religion, then why should any religious identity not be eulogised and appreciated? The need to appreciate individual religions is necessary to maintain harmony and balance of humankind; not deriding of religions in the name of political secularism.

Each religion has its own distinctive contributions to make, and each in its own way is suitable to a particular group of people as they understand life. In fact, every religion teaches man to be good and has its positive aspects, be it the quest for knowledge of Hinduism, the tolerance of Sikhism, the sacrifice embodied by Christianity, the brotherhood of Islam, or the compassion of Buddhism. The world needs them all. ${ }^{15}$ In this context, we can further justify ancient Indian King Ashoka's ( ${ }^{\text {rd }}$ C. B.C) global religiosity even then as is evident in his Rock Edict 12:

\begin{abstract}
Beloved-of-the-Gods, King Piyadasi [Ashoka], desires-that there should be growth in the essentials of all religions. Growth in essentials can be done in different ways, but all of them have as their root restraint in speech, that is, not praising one's own religion, or condemning the religion of others without good cause. And if there is cause for criticism, it should be done in a mild way. But it is better to honour other religions for this reason. By so doing, one's own religion benefits, and so do other religions, while doing otherwise harms one's own religion and the religions of others. Whoever praises his own religion, due to excessive devotion, and condemns others with the thought "Let me glorify my own religion," only harms his own religion. Therefore contact (between religions) is good. One should listen to and respect the doctrines professed by others. Beloved-of-the-Gods, King Piyadasi, desires that all should be well-learned in the good doctrines of other religions. ${ }^{16}$
\end{abstract}

It is pertinent to note in this context that the Ayodhya verdict of the Indian Judiciary is inclusive and exemplary of religious harmony. The much-awaited verdict on the 60 year old Ayodhya title suits was pronounced on September 30, 2010. In this landmark judgment that seeks to find a compromise solution, the Lucknow bench of the Allahabad high court in India ruled that the disputed land at Ayodhya in Uttar Pradesh will be divided among three parties to the suit viz., Hindus, Muslims and the Nirmohi Akhara. The site housed the Babri Masjid which was demolished in 1992 by Hindu protesters who believe that the plot once had a temple marking the birthplace of Lord Rama, the hero of the epic poem, Ramayana. The court ruled that the two communities viz. Hindus and Muslims will be free to build a religious structure on their respective portions of land for worship. ${ }^{17}$ What really matters is that there has been no violence or untoward incidents following the verdict. It has not triggered any untoward communal incident as yet. There is no one single reason to explain that how is it that one of the most sensational and sensitive issues turned out to be so peacefully received and resolved after a decade and more of intense violence, and intolerance and debate? Moreover, both Muslims and Hindus find the judgment below their expectations. Yet all criticism and questioning has been tempered with a maturity that surprised all, and the world. There were no motives attributed to the judiciary, nobody said it was fixed by the government, and nobody said s/he had lost her/his faith in the judicial system. So far no political party has tried to exploit the verdict for partisan purposes. Excerpts from an interview of Justice S. U. Khan, who was one of the Judges who delivered the Ayodhya Verdict is given here:

My judgment is short, very short. Either I may be admired as an artist who knows where to stop, particularly in such a sensitive, delicate matter or I may be castigated for being so casual in such a momentous task. Sometimes patience is intense action, silence is speech and pauses are punches.

The one quality which epitomised the character of Ram [hero of the epic Ramayana] is tyag (sacrifice). When Prophet Mohammad entered into a treaty with the rival group at Hudayliyah, it appeared to be abject surrender even to his staunch supporters. However, the Koran described that as clear victory and it did prove so. Within a short span there from Muslims entered the Mecca as victors, and not a drop of blood was shed.18

Justice Khan quoted Darwin, "Only those species survived which collaborated and improvised." He writes in his epilogue:

Muslims must also ponder that at present the entire world wants to know the exact teachings of Islam in respect of relationship of Muslims with others. [. . . ]. Indian Muslims have also inherited a legacy of religious learning and knowledge. They are therefore in the best position to tell the world the correct position. Let them start with their role in 
the resolution of the conflict at hand. ${ }^{19}$

Such attempts to reconcile differences and to appreciate the importance of other religions were also made in Indian history right from the days of King Ashoka, which authenticates the point that India always stood for concord through religious inclusion. It may be mentioned here that Akbar the Great (1543-1605 A.D), an important Mughal ruler of India, being a firm proponent of universal tolerance and religious freedom for all, welcomed to his court, representatives of all religions known to him, Muslims, Hindus, Jains, Parsis, Jews and even Jesuit priests from the Portuguese settlements in Goa. ${ }^{20} \mathrm{He}$ tried to reconcile the religious differences by creating a new faith called the Din-i-llahi ("Faith of the Divine"), which incorporated both "pantheistic" versions of Islamic Sufism (most notably the Ibn Arabi's doctrine of "Wahdat al Wajood" or Unity of existence) and "bhakti" or devotional cults of Hinduism. Even some elements of Christianity - like crosses, fire worship of Zoroastrianism - were amalgamated besides Jainism in the new religion. Akbar the Great was particularly famous for creating this new pluralistic and synthetic faith. Akbar's all inclusive views are best summarized in the following verses which he himself wrote towards the end of his life:

O god, in every temple I see people that are seeking You, and in every language I hear, people are praising You!

Polytheism and Islam feel after You.

each religion says, 'You are One, without equal!'

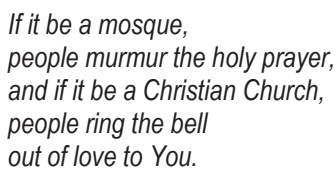

\section{Sometimes I frequent the Christian cloister, and sometimes the} mosque,

but it is You whom I search, from temple to temple. ${ }^{21}$

Hinduism's view that there is one Divine, which may be reached by many paths, has proven throughout the centuries to be a powerful influence upon Hinduism's interaction with other religions. This point of view is expressed clearly in the famous speech delivered by Swami Vivekananda in Chicago on September 11, 1893, an extract of which is given here:
I am proud to belong to a religion which has taught the world both tolerance and universal acceptance... We believe not only in universal toleration, but we accept all religions as true. I am proud to belong to a nation which has sheltered the persecuted and the refugees of all religions and all nations of the earth...and I fervently hope that the bell that tolled this morning in honour of this convention may be the death-knell of all fanaticism, of all persecutions with the sword or with the pen. ${ }^{22}$

These insights are greatly helpful to leaders of today in all domains while dealing with the contemporary and the future issues of development. It tells them not to fight for relics, icons and ideas of the past. A nation is judged by its contemporary status and not by its past. A leader must look with confidence at what s/he can do in the future to better the lives of people rather than digging up the past. ${ }^{23}$

\section{Pillar of Human Inclusion}

Vedanta philosophy which is based on the collective wisdom of generations of seers and sages of India establishes a sound argument for human inclusion. It has been codified in the philosophical texts called Upanishads, Bhagavad Gita and the Brahmasutras. Vedanta philosophy provides insights, which can be of crucial value for the survival of the human race in the twenty first century. According to this philosophy, all human beings are members of a single family and this also is the basis of the concept of human beings as an extended family, vasudhaiva kutumbakam. A popular Sanskrit verse points out that the division between mine and yours is a small and narrow way of looking at reality, indulged in by people with immature minds. For those of the greater consciousness, the entire world is a family:

ayam nijah paroveti ganana laghuchetasam/ udara charitanam tu vasudhaiva kutumbakam/24 
Now we may look into a few dominant personalities who fought for human inclusion and succeeded also in their endeavours. Dr. John R. Mott, a Christian missionary, once asked Mahatma Gandhi, "What have been the most creative experience in your life?" In reply, Mahatma Gandhi narrated events of the night in Maritzburg Station in South Africa where he was thrown out of the train for travelling in the first class compartment because of prejudice against coloured people, even though he had a valid ticket. Mahatma Gandhi decided to fight against colour discrimination which is against human inclusion.

The hardship to which I was subjected was superficial-only a symptom of the deep disease of colour prejudice. I should try, if possible, to root out the disease of colour prejudice and suffer hardships in the process. Redress for wrongs I should seek only to the extent that would be necessary for the removal of the colour prejudice. ${ }^{25}$

Mahatma Gandhi peacefully revolted and after spending about twenty years in peaceful fighting, he returned to India. Gandhi immediately took the side of the people who were discriminated and called 'untouchables' in India.

The untouchables carried out all work- such as cleaning toilets, burying or burning the dead of all castes, sweeping the streets, picking up garbage, etc. They were forbidden from going into temples, hospitals, schools, and many other public places, because they were believed to be unfit, unhealthy and undeserving. Even though Gandhi belonged to a higher caste, his conscience led him to help them. To start a paradigm shift, he renamed the untouchables as Harijans. This literally means God's children. Gandhi took meals with Harijans and cleaned the public toilets along with them. ${ }^{26}$ Gandhi saw that this system was wrong. He traveled across India and at every place his message was the same: 'All human beings are one'. Although Gandhi was a very religious person, he stopped going to temples to pray until they were open to everybody. He told the people gathered around him that, 'There is no God here, if God was here, nobody would be kept out. God is in every one of us.' The people knew that Gandhi was right. Gradually, across India, temples began to open their gates to Harijans. Some people began opening their homes to them as well. Gandhi's strong conviction about the injustice done to untouchables is revealed in the following statements made by him:

\begin{abstract}
... I do not want to attain Moksha [Salvation, merging with God]. I do not want to be reborn. But if I have to be reborn, I should be born, an untouchable so that I may share their sorrows, sufferings and the affronts leveled at them in order that I may endeavour to free myself and them from that miserable condition. ${ }^{27}$

...I think this miserable, wretched, enslaving spirit of 'untouchableness' must have come to us when we were in the cycle of our lives, at our lowest ebb, and that evil has still stuck to us and it still remains with us. ... and you the student world, who receive all this modern education, if you become a party to this crime, it were better that you received no education whatsoever. ${ }^{28}$
\end{abstract}

Another great personality who fought against discrimination and exclusion of human beings is one of the most popular American Presidents viz. Abraham Lincoln who is often described as "The Great Emancipator" and he eventually issued the Emancipation Proclamation, which freed all slaves in those states that were in rebellion. He vigorously supported the 13th Amendment which abolished slavery throughout the United States, and, in the last speech of his life, he recommended extending the vote to African Americans. Lincoln, in a speech at Peoria, Illinois delivered on October 16, 1854 attacked slavery on the grounds that its existence within the United States made American democracy appear hyprocritical in the eyes of the world. He said:

I cannot but hate [the declared indifference for slavery's spread]. I hate it because of the monstrous injustice of slavery itself. I hate it because it deprives our republican example of its just influence in the world. ${ }^{29}$

In a letter to James N. Brown written on October 18, 1858 he said:

I have made it equally plain that I think the negro is included in the word "men" used in the Declaration of Independence. I believe the declaration that "all men are created equal" is the great fundamental principle upon which our free institutions rest; that negro slavery is violative of that principle. ${ }^{30}$

In another letter to Henry L. Pierce written on April 6, 1859 he said:

This is a world of compensations; and he who would be no slave, must consent to have no slave. Those who deny freedom to others, deserve it not for themselves; and, under a just God, cannot long retain it. ${ }^{31}$ 
His Holiness The Dalai Lama coined the phrase "wise self-interest" to define any practical act that involves thinking for others when pursuing personal happiness. And from the premise of a "wise self-interest" he hopes to move towards a better level of human bonding, which he terms as "compromised self-interest". His Holiness argues for human inclusion for everyone's survival. He says:

Today we are so interdependent, so closely interconnected with each other, that without a sense of universal responsibility, a feeling of universal brotherhood and sisterhood, and an understanding and belief that we really are part of one big human family, we cannot hope to overcome the dangers to our very existence - let alone bring about peace and happiness. ${ }^{32}$

\section{Conclusion}

Thus the courses offered by MCHV provide insights on inculcating human values in management students along with developing inclusive mindsets which has become inevitable in the context of a globalized world. In a nutshell, the participating students are guided to adopt innovative approaches that foster understanding and build bridges across ethnic, racial, cultural and religious groups besides promoting social welfare, economic development, and tolerance of all religions, languages and cultures. Caring for the well being of the planet as a whole, together with all its inhabitants (including human beings) and nonliving resources is the focus point of many courses offered by MCHV. Living in harmony with nature and eschewing violence to any form of life, as violence harms the sacred unity and causes suffering which sends life out of balance, is stressed through many examples from classical and contemporary sources.

It is increasingly realized by all stakeholders that educational institutes should promote human values and inclusive mindsets in the wake of sustainability development and inclusive growth. In conclusion it may be wisely pointed out that educational institutes have to concentrate on the development of three pillars of inclusive mindsets in the students namely (1) The Pillar of Environmental Inclusion, (2) The Pillar of Religious Inclusion and (3) The Pillar of Human Inclusion.

\section{References}

Anderson \& Peter Escher, The MBA Oath, portfolio, Penguin, 2010.

Shikhavalli of Taittiriya Upanishad, Ten Principal Upanishads with Sankarabhasya, Motilal Banarsidass, New Delhi, Vol. 1, 1987.

As mentioned in the websites of these Institutes.

Srikant Datar, David Garvin and Patrick Cullen, Rethinking the MBA, Business Education at a Crossroads, Boston: Harvard Business Press, 2010, Pp.103-106.

$<$ http://iimcal.ac.in/centres of excelelnce/centers-of-excellence/management-centre-for-human-values>.

C. Panduranga Bhatta and Pragyan Rath, 'Addressing Human Issues: Experiences of Management Centre for Human Values (IIMC)', paper presented at the Platinum Jubilee Conference on 'Globalisation and Social Transforamation: The Indian Experience' held at Tata Institute of Social Sciences, Mumbai, during Feb. 17-19, 2012. This paper interprets the courses run by MCHV through Derridian philosophy of Deconstruction, and hence evolve a model of analysis of Indian Ethos and its influence on contemporary global practices; a model that establishes potentials or chances of social transformation.

Pragyan Rath, 'Social Issue Is Business Issue': The New Agenda of Lattice 2010, Journal of Human Values, Sage, Vol.17, No.2, Pp. 171 - 172; This paper attempts to establish an intellectual point of departure for an academic discussion of CSR that would initiate further potent research and theorization in this regard.

www.heureka.clara.net/gaia/deep-eco.htm cached April 1, 201310.00 am

C. Panduranga Bhatta, 'Environment Friendly Life Styles: A Dialogue with Ancient India', Decision, Indian Institute of Management Calcutta, Vol. 36, No. 3, December, 2009, Pp. 103-120; Pragyan Rath's interpretation of concepts done for the forth coming book "Leadership Revisited: A Reflective Journey authored by C. Panduranga Bhatta and Pragyan Rath has been adopted here in brief at some places.

H.H. Dalai Lama, 'A Human Approach to World Peace', Journal of Human Values, Sage, Vol. 18, No.2, October, 2012, P. 95; Pragyan Rath's interpretation of this article done for the forthcoming book viz. Leadership Revisited cited above has been adopted here in an abridged form.

N.R. Narayana Murthy, "The Role of Religion in Education" and "In Praise of Secularism" both in A Better India A Better World. New Delhi: Penguin, 2009. Pp. 42-44 and 72-75.

Ven. S. Dhammika, The Edicts of King Ashoka: An English Rendering. Kandy, Berkeley: The Wheel Publication, Buddhist Publication Society, 1993; C. Panduranga Bhatta and Pragyan Rath, Op.cit.

Asghar Ali Engineer and Ram Puniyani, Making Sense of Ayodhya Verdict: Towards Efforts for Peaceful Solution, Vista, Times Group Books, 2011, Pp. 3-20.

Ahmad Bashir, Akbar: The Great Mughul. His New Policy and his New Religion, Aakar Books, Delhi, 2009, Pp. $133-169$. 
Dirk Collier, The Emperor's Writings, Memories of Akbar the Great, Amaryllis, Delhi, 2011, p.592.

Swami Vivekananda On Himself, Advaita Ashrama, Kolkata, Seventh Reprint, 2012, Pp. 128-129; C. Panduranga Bhatta and Pragyan Rath, Op.cit.

N.R. Murthy, Op.cit.

Hitopadesha, Chapter I.Verse,71, Motilal Banrsidas, Delhi, 1967, P.15.

Louis Fischer (ed.), The Essential Gandhi: An Anthology of His Writings on His Life, Work, and Ideas, Mahatma Gandhi, Vintage Spiritual Classics, Vintage Books, New York, 2002, Pp.31-32

URL: http://www.csuchico.edu/cheinz/syllabi/asst001/spring98/india.htm

Raghavan lyer (Ed.) The Essential Writings of Mahatma Gandhi, Oxford University Press, Seventeenth Impression 2007, P.290.

Louis Fischer, Op.cit, P.120.

Collected Works of Abraham Lincoln, The Abraham Lincoln Association, Old State Capitol Plaza, Springfield, Illinois,1953,Vol. II. Pp. $255-256$.

H. H. The Dalai Lama, Op.cit, P.93 and C. Panduranga Bhatta and Prgyan Rath, Op.cit. 